\title{
CHINESE LANGUAGE PROMOTION ACTIVITIES IN ROMANIAN PRIMARY AND SECONDARY SCHOOLS
}

\author{
Wang, YUQIN \\ Beijing Language and Culture University, Beijing, China, e-mail: yuqinwang88@yahoo.com
}

\begin{abstract}
In recent years, with the fast developing of Chinese economy and the bilateral exchanges between China and Romania, more and more Romanian students are willing to learn Chinese. In this context, to analysis how the Chinese teaching activities is taking in the Romanian Primary and Secondary schools, would be very helpful for making both Chinese teaching and learning process more effectively and efficiently.
\end{abstract}

KEY WORDS: Chinese language, primary and secondary school, teaching activity

\section{INTRODUCTION}

With the increasingly bilateral exchanges and cooperation between China and Romania in the fields of politics, economy, culture, education and other aspects, the Chinese teaching and cultural promotion activities of Confucius Institute have been developed quickly in Romania in recent years. China has proposed "the Silk Road Economic Belt and the 21st-century Maritime Silk Road" Initiative, focuses on connectivity and cooperation among countries primarily between China and the rest of Eurasia, among which Romania plays a very important role. Romania and China always have a very good relationship. In order to keep the good relationship, exchange and connection between the two countries, we also need people who know both Romanian and Chinese, therefore, it would be important for the students from both countries to learn the language of each other.

This paper focuses on Chinese teaching in primary and secondary schools in Romania, and some of the problems encountered in teaching Chinese were also mentioned.

\section{THE OVERVIEW OF CHINESE TEACHING IN ROMANIAN PRIMARY AND SECONDARY SCHOOLS}

The start of Chinese teaching in Romanian primary and secondary schools was after the establishment of Confucius Institute at Lucian Blaga University of Sibiu, which was the first Confucius Institute in Romania. In recent years, we have seen that more and more Chinese investors have come to Romania for collaboration and investments, more and more people are becoming interested in learning Chinese language and culture. We have now four Confucius Institutes in Romania, Confucius Institute at Lucian Blaga University of Sibiu, Confucius Institute at Babes-Bolyai University of ClujNapoca, Confucius Institute at Transilvania University of Brasov and Confucius Institute at the University of Bucharest.
There are almost 5300 students from approximate 50 primary and secondary schools, who are learning Chinese language and culture, mainly from Sibiu, Cluj, Brasov, Bucharest, Timisoara, Iasi, Constanta, Craiova, Galati, Pitesti, Arad, Bacau, Targu Mures, Deva, Hunedoara, Petrosani, Harghita, Suceava, Alba Iulia, Giurgiu, Bistrita and other cities.

\section{SEVERAL THOUGHTS ON CHINESE LANGUAGE PROMOTION ACTIVITIES IN ROMANIAN PRIMARY AND SECONDARY SCHOOLS}

The Chinese language promotion activities in Romanian primary and secondary schools have been very fruitful during the last several years. From one hand, Confucius Institute has made great efforts for being a multi-platform for the students to have a better understanding of China and Chinese culture; From the other hand, after the official visit of China's Premier $\mathrm{Li}$ Keqiang to Romania in 2013, a series of cooperation agreements were signed between the two countries, the relationship between China and Romania has entered a new era, more and more people realize that to know Chinese is very important; The rapid economic growth of China also makes Chinese learning in a high demand. With all of these, we believe that Chinese will be the language of the future.

As a Chinese teacher of Confucius Institute at Lucian Blaga University of Sibiu, after 6 years of teaching Chinese in Romanian schools, I would like to summarize the situation and some problems encountered during the teaching activities from these aspects:

1. For the primary and secondary schools in Romania which we already have taken the Chinese teaching activities, most of them, have the collaboration with Confucius Institute, which is also the outcome of Confucius Institute's active promoting activities. We believe that, the partnerships concluded between the Confucius Institute 
and the local authorities, School Inspectorates would assure the sustainable developing of Chinese courses in the schools. With the cooperation agreement guaranteed, more schools will look for instead of waiting for the collaborations for Chinese teaching activities.

2. For the Chinese courses we have in these almost 50 schools, although there are several schools, the Chinese course has been already taken as an optional discipline in the school curriculum; but for most of the schools, the Chinese course is out of the school curriculum, which means, the students need to stay more after they finish the outline courses. For the primary school and secondary school students, at an age of expecting more fun and colorful life, they need to be really interested in Chinese language and culture to stay over the school schedule.

We've did a research on why the students want to learn Chinese, most of the students choose that they are interested in Chinese culture, the other reasons would be: China's fast developed economy makes Chinese learning necessary; being interested in the Asian culture; want to go to China to travel; want to study in China in the future; enjoy Chinese movies and music; There are also some students, they choose to learn Chinese just because of curiosity.

However, Chinese is not an easy language to learn for Romanians. To stay over the school schedule to learn two months of Chinese still seems Ok for them, but when the study becomes harder, like to learn any other languages, some students would start to give up the learning.

When taking the Chinese teaching activities for primary and secondary school students, the teacher should guide the students to learn in an active way, introduce culture aspects while teaching the language, try to make the teaching activities more interesting. Learning Chinese through Chinese movies and Chinese songs could also be a very good way.

The teachers can help the students to set a short-term goal, e.g. to pass the first level of Chinese HSK examination after 8 months of learning, so he could also participate the summer school in China; to get one year of scholarship in China after passing the third level of HSK, etc. Each year, there are also students getting the chance of visiting China through the participation of the "Chinese Bridge" Chinese Proficiency Competition for Secondary School Students.

We've seen that more and more Chinese companies are coming to Romania for investments and collaboration, to learn Chinese would also be very helpful for the future career plans.

3. In Romania, the main teaching materials used are "Happy Chinese", "Learn Chinese with me", "Road to Success" and "Chinese Paradise" etc. Actually not a lot of Chinese learning books could be found in the local book stores. In my opinion this could be an aspect which we should work for, to develop a series of teaching materials to meet the needs of the locals.

For the teachers, we should choose different kinds of books, different ways of teaching method for different group of students; pay attention to each individual's needs, make sure everybody could learn something from each single lesson, and try to maximize the teaching effectiveness.

With the development of bilateral economic relations between China and Romania, the cultural and educational exchanges between the two countries are more frequently. More and more people are willing to understand China, to visit China or to study in China. We've seen that a lot of parents want their children to learn, and more and more students are interested to learn Chinese, a language which they believe would be quite useful in the future. As the Chinese teachers at Confucius Institute, we should try our best to do as much as we can for those who are interested in Chinese language and culture, to have a better understanding of China, in order to promote the mutual understanding between both countries.

\section{BIBLIOGRAPHY:}

1. Zhu, Zhiping (2010). "A Historical Perspective of Teaching Chinese as a Second Language". In Teaching and Learning Chinese: Issues and Perspectives

2. "Pedagogical Issues Raised and Discussed in The Chinese Repository"' (2001). Journal of the Chinese Language Teachers Association

3. https://en.wikipedia.org/wiki/One_Belt,_One_Road 